\title{
PERBEDAAN REAKSI PASAR PADA PERUSAHAAN PEMENANG INDONESIA SUSTAINABILITY REPORTING AWARD (ISRA) (Studi pada Perusahaan Pemenang ISRA periode 2009-2011)
}

\author{
Randika Bagus Linuwih ${ }^{1)}$ \\ Yeterina Widi Nugrahanti ${ }^{2}$ \\ ${ }^{1)}$ Alumni Fakultas Ekonomika dan Bisnis Universitas Kristen Satya Wacana \\ ${ }^{2)}$ Fakultas Ekonomika dan Bisnis Universitas Kristen Satya Wacana, \\ e-mail: yeterina.nugrahanti@staff.uksw.edu
}

\begin{abstract}
The purpose of this study is to examine the change of market reaction arround the date of Indonesia Sustainability Reporting Award (ISRA) announcement. The market reaction is measured by abnormal return and trading volume activity. The sample of the study consist of 25 companies listed on the Indonesian Stock Exchange which accept the appreciation of ISRA in 2009-2011. Data that used in this study consist of share's daily closing price and daily trading volume. The estimation period is 30 days and event period is 11 days by using Market Models. Technique of analyzed for examining the hypothesis is Wilcoxon Sign Test at level significant of $10 \%$. The results of this research show that ISRA announcement didnot get any response from the investors, because there were no significant changes to the abnormal return before and after the announcement. The examination of trading volume activity proves that there are any significant differences in trading volume activity especially on fifth day and second day before the announcement, and the first day and second day after ISRA 2009-2011 announcement.
\end{abstract}

Keywords: Indonesia sustainability reporting award, sustainability reporting, abnormal return, trading volume activity

\section{PENDAHULUAN}

Sebuah event penghargaan merupakan sebuah bentuk apresiasi kepada pihak-pihak yang memiliki prestasi di bidang tertentu. Beberapa penghargaan yang diberikan kepada perusahaan tentunya dapat membuat perusahaan berlomba-lomba untuk melakukan yang terbaik, dengan harapan perusahaan tersebut memiliki reputasi yang bagus dan berbanding lurus dengan prestasinya. Apabila perusahaan memiliki reputasi yang bagus, maka investor akan tertarik untuk berinvestasi di perusahaan tersebut. Di Indonesia, terdapat beberapa penghargaan yang mengapresiasi kinerja perusahaan dalam hal pelaporan, seperti Annual Report Award (ARA), Indonesia Corporate Social Responsibility Award (ICSRA), dan Indonesia Sustainability Reporting Award (ISRA). Salah satu penghargaan di bidang pelaporan sustainabilitas adalah Indonesia Sustainability Reporting Award (ISRA), penghargaan ini fokus terhadap kinerja perusahaan dalam melaporkan aspek ekonomi, sosial, dan lingkungan dari bisnisnya. Pelaporan sustainabilitas merupakan salah satu bentuk dari pelaporan keuangan, yang mana sampai saat ini pelaporan sustainabilitas tersebut masih bersifat sukarela.

Pelaporan keuangan merupakan salah satu wujud pertanggungjawaban manajemen terhadap pihak-pihak yang berkepentingan terhadap perusahaan selama periode 
tertentu (Hamzah, 2007). Menurut Satyo (2005) dalam Budiman dan Supatmi (2009), pengungkapan aspek social, ethical, environmental dan sustainability (SEES) sekarang ini menjadi suatu cara bagi perusahaan untuk mengkomunikasikan bentuk akuntabilitasnya kepada para stakeholders. Sustainability reporting sebagaimana direkomendasikan oleh Global Reporting Initiative (GRI) terfokus pada tiga aspek kinerja yaitu ekonomi (economic), lingkungan (environmental), dan sosial (social). Menurut Anggraini (2007), sebuah perusahaan yang ingin berkelanjutan harus memperhatikan " $3 \mathrm{P}$ ”. Perusahaan tidak hanya berfokus untuk memaksimalkan laba (profit), tetapi harus juga memperhatikan masyarakat (people) dan ikut serta dalam melestarikan dan menjaga lingkungan (planet). Ketiga aspek ini dikenal dengan triple bottom line. Dengan adanya bentuk pelaporan sustainabilitas ini diharapkan perusahaan mempunyai kinerja yang baik dalam menerapkan Corporate Social Responsibility (CSR) dan diharapkan kinerja perusahaan secara keseluruhan meningkat.

Masalah lingkungan hidup kini menjadi sesuatu yang sangat penting bagi perusahaan, karena di samping melakukan produksi, perusahaan juga tidak boleh merusak lingkungan sekitarnya. Perusahaan harus melakukan restorasi atas kerusakan yang ditimbulkan atas proses produksi perusahaan. Laporan keuangan menurut Statement of Financial Accounting Concepts 8 (2010) merupakan salah satu sumber informasi dan merupakan salah satu alat ukur yang dipakai oleh para stakeholders untuk menilai kinerja perusahaan, dan sebagai pertimbangan dalam membuat keputusan investasi, kredit, dan keputusan serupa lainnya.

Perhatian pelaku bisnis terhadap pelaporan ekonomi, sosial dan lingkungan semakin meningkat seiring dengan banyaknya kasus lingkungan yang terjadi di Indonesia. Sebagai contoh kasus lumpurlapindo (PT Minarak Lapindo) dan kasus pencemaran Teluk Buyat (PT Newmont Minahasa Raya) membuat perusahaan dituntut untuk mengungkapkan informasi-informasi non-keuangan di dalam laporan keuangannya, salah satunya adalah informasi tentang lingkungan dan sosial. Perusahaan terdorong untuk melakukan pengungkapan informasi lingkungan dan sosial untuk meningkatkan reputasi, keunggulan kompetitif, dan manajemen risiko (Budiman dan Supatmi, 2009). Hal ini berarti apabila perusahaan tidak memperhatikan isu tentang kerusakan lingkungan dan sosial akan mengakibatkan reputasi perusahaan menurun sehingga para investor enggan berinvestasi di perusahaan tersebut. Keengganan investor melakukan investasi akan menyebabkan perusahaan kehilangan salah satu sumber pendanaan bagi kelangsungan hidup perusahaan itu sendiri, yang seharusnya bisa didapatkan apabila perusahaan memiliki reputasi yang bagus, yaitu dengan lebih mempedulikan lingkungan dan sosial.

Untuk memberikan apresiasi terhadap perusahaan yang telah menerapkan pengungkapan informasi lingkungan dan sosial dalam laporan keuangannya, dimulai pada tahun 2005, Ikatan Akuntan Indonesia Kompartemen Akuntan Manajemen (IAIKAM) menyelenggarakan Indonesia Sustainability Reporting Awards (ISRA). ISRA merupakan sebuah event penghargaan yang ditujukan untuk perusahaan yang telah menerapkan Sustainability Reporting. Pemberian penghargaan atas pencapaian seperti ini tentunya mengundang reaksi pasar. Meskipun penerapan sustainability reporting di Indonesia adalah secara suka rela atau voluntary, namun hal ini merupakan salah satu pertimbangan investor dalam pengambilan keputusan investasi. Perusahaan-perusahaan pemenang ISRA mempunyai pengungkapan pelaporan mengenai aspek lingungan dan sosial yang baik, di samping aspek ekonomi. Dengan adanya informasi perusahaan yang memenangkan award tersebut, investor dan calon investor dapat mengetahui kinerja 
perusahaan sehingga memberikan rasa aman ketika menanamkan modal dan investor berharap memperoleh return yang tinggi. Perusahaan pemenang ISRA dinilai mempunyai reputasi yang bagus karena dianggap mempunyai prospek yang baik di masa yang akan datang sehingga kemungkinan besar investor dan calon investor memiliki minat yang besar dalam menanamkan modalnya.

Beberapa penelitian sebelumnya tentang reaksi pasar seperti yang dilakukan Suwarno (2005), Kartini dan Dion (2007) menyimpulkan bahwa pemberian Annual Report Award (ARA) direspon oleh pasar. Hal ini dibuktikan dengan adanya perbedaan abnormal return dan volume perdagangan saham di seputar tanggal pengumuman. Sedangkan Saputro (2005) menemukan tidak adanya perbedaan abnormal return dan volume perdagangan saham di seputar tanggal pengumuman ISRA 2005. Harsono (2009) juga menemukan bahwa pemberian Indonesian Corporate Social Responsibility Award (ICSRA) 2005 tidak berdampak terhadap abnormal return. Budiman dan Supatmi (2009) menemukan bahwa ada perbedaan abnormal return pada sekitar tanggal pengumuman ISRA 2005-2008, namun tidak ada perbedaan dalam volume perdagangan saham. Sedangkan penelitian Idealfa (2011) menemukan bahwa terdapat perbedaan abnormal return maupun volume perdagangan saham pada pengumuman ICSRA tahun 2005 dan 2008.

Penelitian ini merupakan replikasi dari penelitian dari Budiman dan Supatmi (2009) yang menguji apakah ada perbedaan abnormal return dan volume perdagangan saham pada sekitar tanggal pengumuman ISRA 2005-2008. Penelitian ini penting untuk dilakukan mengingat hasil penelitian sebelumnya mengena ireaksi pasar di seputar pengumuman ISRA masih menunjukkan hasil yang belum konsisten. Selain itu, jumlah perusahaan yang telah menerapkan Sustainability Reporting semakin meningkat dari tahun ke tahun seperti ditunjukkan pada gambarl berikutini:

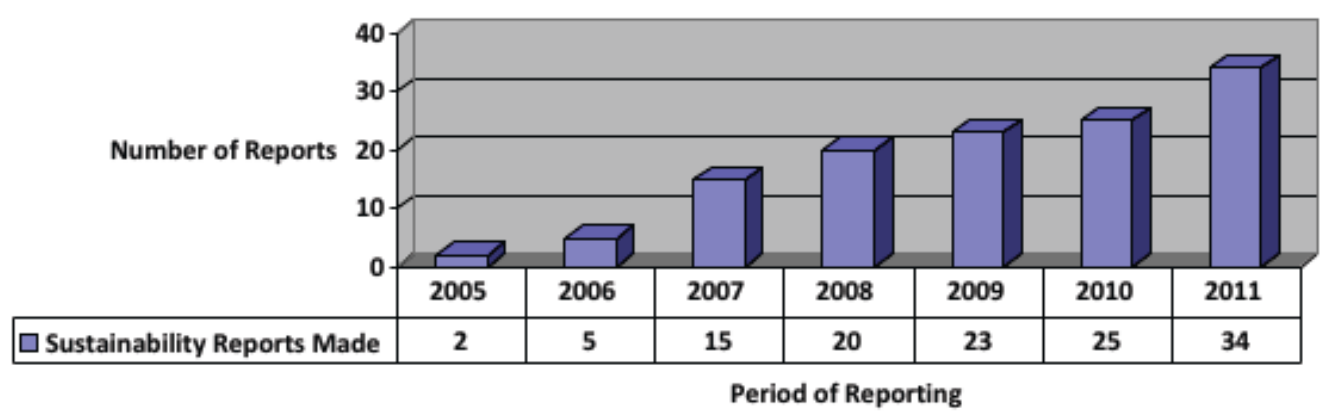

$\square$ Sustainability Reports Made

Sumber: www.ncsr-id.org

Gambar 1. Jumlah Perusahaan yang Melaporkan Sustainability Report

Meneruskan penelitian sebelumnya, penelitian ini menggunakan periode 2009-2011 yang diharapkan dapat menggambarkan kondisi pasar yang terbaru. Selain itu banyaknya kasus kerusakan lingkungan akhir-akhir ini, diharapkan penelitian ini mampu menemukan bukti bahwa pengumuman ISRA ditanggapi positif oleh pasar. Pengkategorian pemenang ISRAtahun 2009, 2010, dan 2011 berbeda dengan pemenang ISRA periode-periode sebelumnya di mana peserta dan pemenang ISRA pada periode terdahulu lebih sedikit dibandingkan pada tahun 2009, 2010, dan 2011. Pada penelitian terdahulu perusahaan- 
perusahaan yang berada di posisi runner-up tidak dicantumkan, padahal perusahaanperusahaan yang menjadi runne-up pun memiliki pelaporan sustainabilitas yang lebih baik baik dari perusahaan peserta ISRA yang tidak memenangkan kategori penghargaan ISRA.

Dengan mempertimbangkan banyaknya kasus lingkungan yang terjadi akhir-akhir ini serta perbedaan-perbedaan pengkategorian pemenang ISRA tahun 2009, maka penelitian ini ingin melihat kembali perbedaan reaksi pasar di seputar pengumuman ISRA. Penelitian ini bertujuan untuk mengevaluasi dan menganalisis perbedaan reaksi pasar sebelum dan sesudah pengumuman Indonesia Sustainability Reporting Award (ISRA) adanya reaksi pasar terhadap pengumuman ISRA dilihat dari abnormal return saham dan volume perdagangan saham pada periode 2009-2011. Baik abnormal return maupun volume perdagangan saham adalah salah satu indikasi untuk mengukur reaksi pasar terhadap sebuah event atau kejadian. Keduanya dipilih karena hasil yang diperoleh tidak selalu merepresentasikan hasil yang menyeluruh dan hasil yang sama, seperti pada penelitian Budiman dan Supatmi (2009) yang menemukan adanya perbedaan abnormal return sedangkan tidak demikian pada volume perdagangan sahamnya.

Penelitian ini penting untuk dilakukan karena hasil penelitian sebelumnya menunjukkan hasil yang belum konsisten. Selain itu perbedaan pengkategorian pemenang ISRA tahun 2009 dimungkinkan akan menimbulkan reaksi yang berbeda dari investor. Manfaat penelitian ini bagi perusahaan yaitu dengan mengungkapkan informasi tentang kondisi economic (ekonomi), kondisi social (sosial), dan kondisi environtmental (lingkungan) dalam laporan tahunan, diharapkan dapat memberi masukan kepada perusahaan akan pentingnya penerapan konsep sustainability reporting. Dengan menerapkan dan mengungkapkan konsep sustainability reporting maka perusahaan akan mendapat citra positif dari masyarakat sehingga pada akhirnya meningkatkan minat investor dan calon investor dalam melakukan investasi pada perusahaan sebagai sumber pendanaan perusahaan. Bagi investor, penelitian ini dapat memberikan informasi tambahan sebagai bahan pertimbangan dalam melakukan pengambilan keputusan investasi.

\section{Telaah Teoritis dan Pengembangan Hipotesis}

Penelitian mengenai reaksi pasar sering dikaitkan dengan teori efisiensi pasar dan event study. Berikut ini akan dibahas teori dan konsep yang digunakan dalam penelitian ini.

Teori Efisiensi Pasar. Teori Efisiensi Pasar berkaitan dengan bagaimana suatu pasar bereaksi terhadap suatu informasi (Hartono, 1998). Bentuk efisiensi pasar tidak hanya dapat dilihat dari segi ketersediaan informasinya saja, tetapi juga dilihat dari kecanggihan pelaku pasar dalam pengambilan keputusan berdasarkan analisis dari informasi yang tersedia. Pasar efisien yang ditinjau dari sudut informasinya saja disebut efisiensi pasar secara informasi (informationally efficient market), sedangkan pasar efisien yang ditinjau dari sudut kecanggihan pelaku pasar dalam mengambil keputusan berdasarkan informasi yang tersedia disebut dengan efisiensi pasar secara keputusan (decisionally efficient market).

Untuk mengukur pasar yang efisien, kunci utamanya adalah hubungan antara harga sekuritas dengan informasi yang tersedia. Fama (1970) dalam Hartono (1998) membagi efisiensi pasar kedalam tiga bentuk, yaitu:

1. Efisiensi pasar bentuk lemah

Pasar dikatakan bentuk lemah jika harga-harga sekuritas secara penuh mencerminkan 
informasi masa lalu, yang artinya data masa lalu tidak berhubungan dengan nilai sekarang. Nilai-nilai masa lalu tidak bisa digunakan untuk memprediksi harga sekarang, yang artinya investor tidak dapat menggunakan informasi masa lalu untuk mendapatkan abnormal return.

2. Efisiensi pasar bentuk setengah kuat

Pasar dikatakan bentuk setengah kuat jika harga-harga sekuritas mencerminkan semua informasi yang dipublikasikan termasuk informasi yang berada dalam laporanlaporan perusahaan emiten. Informasi yang dipublikasikan dapat berupa:

a. Informasi yang dipublikasikan yang hanya mempengaruhi harga sekuritas perusahaan yang mempublikasikan informasi tersebut. Sebagai contoh yaitu adanya corporate action dari emiten (pengumuman laba, pembagian dividen, pengumuman merjer dan akuisisi, dan lain-lain)

b. Informasi yang dipublikasikan yang mempengaruhi harga-harga sekuritas beberapa perusahaan. Sebagai contoh peraturan pemerintah atau peraturan regulator yang berdampak pada perusahaan tertentu.

c. Informasi yang dipublikasikan yang mempengaruhi harga-harga sekuritas semua perusahaan yang terdaftar di pasar saham.

Jika pasar efisien setengah kuat, maka tidak ada investor atau grup investor yang dapat menggunakan informasi yang dipublikasikan untuk mendapatkan keuntungan tidak normal (abnormal return) dalam jangka waktu lama.

3. Efisiensi pasar bentuk kuat

Pasar dikatakan efisien dalam bentuk kuat jika harga-harga sekuritas secara penuh mencerminkan semua informasi yang tersedia termasuk informasi privat. Jika pasar efisien dalam bentuk kuat, maka tidak ada investor maupun grup investor yang dapat memperoleh abnormal return karena mempunyai informasi privat.

Event Study. Penelitian ini merupakan sebuah studi peristiwa. Studi peristiwa (event study) merupakan studi yang mempelajari reaksi pasar terhadap suatu peristiwa (event) yang informasinya dipublikasikan sebagai suatu pengumuman. Event study dapat digunakan untuk menguji kandungan informasi dari suatu pengumuman dan dapat juga untuk menguji efisiensi pasar bentuk setengah kuat (Hartono, 1998). Pengujian kandungan informasi dan pengujian efisiensi pasar bentuk setengah kuat merupakan dua pengujian yang berbeda. Pengujian kandungan informasi dimaksudkan untuk melihat reaksi dari suatu pengumuman. Jika pengumuman mengandung informasi, diharapkan pasar akan bereaksi pada waktu pengumuman tersebut diterima oleh pasar. Reaksi pasar ditunjukkan dengan adanya perubahan harga sekuritas bersangkutan. Reaksi ini dapat diukur dengan menggunakan abnormal return. Hartono (1998) mengemukakan bahwa suatu pengumuman yang mempunyai kandungan informasi akan memberikan abnormal return kepada pasar, sedangkan suatu pengumuman tidak mengandung informasi maka pengumuman tersebut tidak akan memberikan abnormal return kepada pasar.

Sustainability Reporting. Sembiring (2003) menyatakan bahwa pelaporan sustainabilitas terkait dengan tanggung jawab perusahaan terhadap lingkup yang lebih luas dari kelompok pemegang saham dan kreditur saja, dengan kata lain pelaporan sustainabilitas merupakan tanggung jawab perusahaan terhadap stakeholders. Freedman (1962) dalam Grey et. al., (1995) menyatakan tanggung jawab sosial perusahaan untuk memaksimalkan laba tidak lagi diterima secara universal. Tanggung jawab sosial perusahaan digambarkan sebagai ketersediaan informasi keuangan maupun non-keuangan berkaitan dengan 
interaksi organisasi dengan lingkungan fisik dan lingkungan sosialnya, yang dapat dibuat dalam laporan tahunan perusahaan atau laporan sosial terpisah (Guthrie dan Mathews, 1985). Laporan keberlanjutan (sustainability reporting) adalah praktek pengukuran, pengungkapan dan upaya akuntabilitas dari kinerja organisasi dalam mencapai tujuan pembangunan berkelanjutan. Sustainability Reporting menggambarkan laporan mengenai dampak ekonomi, lingkungan, dan sosial (triple bottom line).

The Asociation of Chartered Certified Accountants (ACCA) (2004) dalam Anggraini (2006) mendefinisikan sustainability reporting adalah pelaporan mengenai kebijkan ekonomi, lingkungan, dan sosial, pengaruh dan kinerja organisasi dan produknya di dalam konteks pembangunan berkelanjutan (sustainable development). Darwin (2004) mengatakan bahwa corporate sustainability reporting dibagi menjadi tiga kategori yaitu kinerja ekonomi, kinerja lingkungan, dan kinerja sosial. Kinerja ekonomi antara lain terkait dengan pelanggan, pemasok, karyawan, penyedia modal, dan sektor publik. Kinerja lingkungan adalah beberapa hal yang terkait dengan lingkungan, seperti bahan baku, air, energi, emisi, sungai, sampah, pelaksanaan produksi, pengangkutan, dan lainlain. Kinerja sosial antara lain meliputi praktik kerja yaitu keselamatan dan keamanan tenaga kerja, pendidikan dan pelatihan, serta kesempatan kerja; hak manusia yaitu nondiskriminatif, tenaga kerja di bawah umur, kebebasan berserikat dan berkumpul, dan lain-lain; sosial yaitu korupsi, penetapan harga; serta tanggung jawab pada produk yaitu kesehatan dan keamanan pelanggan, iklan yang peduli terhadap hak pribadi.

Implementasi pelaporan berkelanjutan di Indonesia didukung oleh sejumlah aturan seperti UU No 23/1997 tentang manajemen lingkungan, aturan yang dikeluarkan Bursa Efek Indonesia mengenai prosedur dan persyaratan listing dan PSAK (Sihotang, 2008). Pelaporan pelaksanaan tanggung jawab sosial dan lingkungan dalam laporan tahunan perseroan terbatas di Indonesia telah diwajibkan melalui Pasal 66 Ayat 2 Undang-Undang No.40/ 2007 tentang Perseroan Terbatas. Sejak beberapa tahun terakhir Bapepam-LK telah pula mengeluarkan aturan yang mengharuskan emiten mengungkapkan pelaksanaan kegiatan Corporate SocialResponsibility (CSR) di dalam laporan tahunan perusahaan (Darwin, 2008).

Indonesia Sustainability Reporting Award (ISRA). Dimulai pada tahun 2005, atas kerja sama Ikatan Akuntan Indonesia dan National Center for Sustainability Reporting (NSCR), yang beranggotakan Indonesian Netherlands Association (INA), Forum for Corporate Governance in Indonesia (FCGI), Komite Nasional Kebijakan Governance (KNKG) dan Asosiasi Emiten Indonesia (AEI) mengadakan even penghargaan yaitu Indonesia Sustainability Reporting Awards (ISRA) sebagai bentuk apresiasi terhadap perusahaanperusahaan yang telah melakukan laporan berkelanjutan (sustainability reporting), baik yang diterbitkan secara terpisah maupun terintegrasi dalam laporan tahunan (annual report). Tentunya perusahaan pemenang ISRA adalah perusahaan yang baik dan mampu menyajikan laporan keuangan yang sustainable yaitu yang menyangkut aspek sosial dan lingkungan di samping aspek ekonomi untuk memelihara keberlanjutan (sustainability) perusahaan itu sendiri. Tujuan ISRA yang tercantum dalam www.ncsr-id.org adalah sebagai berikut: (1) memberikan pengakuan terhadap organisasi-organisasi yang melaporkan dan mempublikasikan informasi mengenai lingkungan, sosial, dan informasi keberlanjutan terintegrasi. (2) mendukung pelaporan di bidang lingkungan, sosial, dan keberlanjutan. (3) meningkatkan akuntabilitas perusahaan dengan menekankan tanggung jawab terhadap pemangku kepentingan utama (key stakeholders). (4) meningkatkan kesadaran perusahaan terhadap transparansi dan pengungkapan. 
Adanya ISRA bermanfaat agar perusahaan lebih memperhatikan pengungkapan aspek kinerja ekonomi, lingkungan, dan sosial yang berkaitan erat dengan keberlangsungan perusahaan di masa yang akan datang. Apabila pengungkapan tersebut baik, perusahaan akan dianggap investor dan calon investor memiliki kemanfaatan ekonomis yang besar di masa yang akan datang mendapatkan nama baik di mata masyarakat, peluang untuk menarik investor juga semakin besar, serta dapat mengelola sumber daya dengan baik sehingga menghasilkan produk berkualitas.

Reaksi Pasar. Hartono (1998) menjelaskan bahwa reaksi investor atas sebuah peristiwa dapat dilihat dari terjadinya abnormal return saham dan perubahan volume perdagangan saham di seputar peristiwa tersebut. Beaver (1968) dalam Bandi dan Hartono (1999) perbedaan penting antara pengujian harga dan volume adalah bahwa harga merefleksikan perubahan dalam pengharapan pasar sebagai suatu keseluruhan sedangkan volume merefleksikan perubahan dalam pengharapan investor individual. Suatu informasi, misalnya pengumuman ISRA award mungkin tidak mengubah pengharapan pasar sebagai suatu keseluruhan tetapi mungkin mengubah pengharapan individual. Dalam situasi seperti itu, maka tidak akan ada reaksi harga, tetapi mungkin ada pergerakan reaksi volume.

Abnormal Return Saham. Investor melakukan investasi dengan tujuan untuk mendapatkan return. Return dapat berupa return yang sesungguhnya atau yang sudah terjadi dan return ekspektasi, yaitu return yang belum terjadi tetapi diharapkan akan terjadi di masa yang akan datang. Perbedaan return ekspektasi dengan return realisasi yang sesungguhnya terjadi pada suatu surat berharga pada saat tertentu disebut abnormal return. Return suatu surat berharga sangat terkait dengan perbedaan harga periode tertentu dengan harga periode sebelumnya. Harga suatu surat berharga pada saat tertentu sangat ditentukan oleh keputusan pelaku pasar. Pada sisi lain keputusan harga tersebut sangat dipengaruhi banyak faktor, misalnya adanya pengumuman laporan keuangan atau adanya berita baru (Jones, 1996 dalam Bandi dan Hartono, 1999).

Menurut Hartono (1998) abnormal return merupakan kelebihan dari return yang sesungguhnya terhadap return normal, dimana return normal merupakan return ekspektasi (return yang diharapkan investor). Sehingga return yang tidak normal (abnormal return) adalah selisih antara return sesungguhnya dengan return ekpektasi. Return sesungguhnya adalah return yang terjadi pada waktu ke-t yang merupakan selisih harga sekarang relatif terhadap harga sebelumnya. Return ekspektasi adalah return yang harus diestimasi.

Volume Perdagangan Saham. Menurut Budiman dan Supatmi (2009), trading volume activity (TVA) merupakan indikator yang digunakan untuk menunjukan besarnya minat investor pada suatu saham. Semakin besar volume perdagangan berarti transaksi terhadap saham tersebut meningkat seiring dengan membesarnya volume perdagangannya. Jika investor menganggap informasi tentang penghargaan Indonesia Sustainability Reporting Award sebagai hal yang positif, maka reputasi perusahaan di mata investor dan calon investor akan meningkat sehingga dengan meningkatnya reputasi perusahaan akan meningkatkan minat investor dan calon investor terhadap saham perusahaan peraih penghargaan ISRA. Peningkatan permintaan akan saham mengakibatkan semakin banyak saham perusahaan pemenang yang diperdagangkan, sehingga trading volume activity akan naik.

Perusahaan tidak hanya mengejar keuntungan ekonomis semata, namun lebih memperhatikan aspek sosial dan lingkungan karena berhubungan dengan keberlanjutan 
perusahaan itu sendiri. Investor dapat menilai itu semua melalui ISRA. Perusahaan pemenang ISRA dinilai oleh investor memiliki prospek yang cerah di masa yang akan datang sehingga dapat menumbuhkan minat investor maupun calon investor untuk melakukan investasi pada perusahaan pemenang ISRA.

Untuk mengetahui pengaruh ISRA tahun 2009-2011 digunakan indikator trading volume activity sebagai ukuran yang mencerminkan kegiatan perdagangan saham perusahaan-perusahaan peraih penghargaan ISRA selama tahun 2009-2011. Trading volume activity digunakan untuk melihat apakah investor menilai pengumuman ISRA memberikan pengaruh pada pengambilan keputusan. Hal tersebut dapat dilihat melalui tinggi rendahnya volume perdagangan pada hari-hari di seputar pengumuan ISRA 20092011.

Pengukuran abnormal return maupun volume perdagangan saham adalah salah satu indikator untuk mengukur reaksi pasar terhadap sebuah event atau kejadian. Keduanya dipilih karena reaksi pasar dalam bentuk abnormal return saham tidak selalu sama dengan reaksi perubahan volume perdagangan saham.

\section{Pengembangan Hipotesis}

Menurut Hartono (1998) return saham adalah hasil yang diperoleh dari investasi saham. Abnormal return merupakan selisih antara return yang sesungguhnya terjadi (actual return) dan return yang diharapkan investor (expected return). Indonesia Sustainability Reporting Award (ISRA) merupakan penghargaan yang diberikan kepada perusahaan-perusahaan yang telah membuat pelaporan atas kegiatan yang tidak hanya menyangkut maksimalisasi profit, namun juga kepedulian perusahaan terhadap lingkungan alam dan lingkungan sosial. Satyo (2005) dalam Budiman dan Supatmi (2009) mengatakan bahwa para investor mengalami perubahan pandangan investasi, dengan mulai mempertimbangkan kepedulian perusahaan terhadap lingkungan. Berdasarkan penelitian Eipstein dan Freedman (1994) dalam Anggraini (2006) menemukan bahwa investor tertarik terhadap informasi sosial yang dilaporkan dalam laporan keuangan.

Seiring dengan perkembangan waktu, para investor dan calon investor tidak hanya mempertimbangkan laba perusahaan atau aspek ekonomi saja, melainkan juga mempertimbangkan aspek kepedulian perusahaan terhadap lingkungan alam dan lingkungan sosial. Sehingga pengumuman Indonesia Sustainability Reporting Award (ISRA), diharapkan berguna bagi investor maupun calon investor dalam pengambilan keputusan investasi. Perusahaan-perusahaan pemenang ISRA tentunya mempunyai pengungkapan pelaporan mengenai aspek lingungan dan sosial yang baik, di samping aspek ekonomi tentunya. Dengan adanya informasi perusahaan yang memenangkan award tersebut, maka investor dan calon investor dapat mengetahui kinerja perusahaan pemenang tersebut sehingga memberikan rasa aman ketika menanamkan modal sahamnya dan tentunya untuk memperoleh return yang tinggi. Perusahaan pemenang ISRA dinilai mempunyai reputasi yang bagus karena dianggap mempunyai prospek yang cerah di masa yang akan datang sehingga kemungkinan besar investor dan calon investor memiliki minat yang besar dalam menanamkan modalnya.

Harijono (1999) dalam Mulia (2005) mengungkapkan bahwa dampak positif yang dirasakan perusahaan adalah kecenderungan harga saham akan naik yang dapat diukur dengan abnormal return saham. Pengumuman yang mengandung informasi akan memberikan abnormal return kepada pasar secara konsisten. Jadi jika pengumuman ISRA dianggap mengandung informasi, maka pasar akan menunjukan perubahan harga, 
reaksi pasar yang menunjukan perubahan harga tersebut dapat diukur dengan abnormal return saham.

Harsono (2009) yang meneliti dampak Indonesian CSR Award 2005 terhadap abnormal return saham, membuktikan bahwa ternyata tidak ada perbedaan yang signifikan antara abnormal return pada tanggal pengumuman Indonesian CSR Award 2005 dengan rata-rata harian abnormal return sebelum pengumuman dan sesudah pengumuman tersebut. Hasil penelitian tersebut berbeda dengan penelitian tentang event study tentang reaksi pasar terhadap suatu penghargaan lainnya.

Suwarno (2005) melakukan penelitian yang menguji apakah penghargaan Annual Report Award (ARA) 2004 direspon positif oleh investor di pasar. Hasil pengujian menunjukkan adanya nilai rata-rata abnormal return yang terus meningkat, berarti saham perusahaan penerima ARA 2004 direspon positif oleh pasar. Hasil penelitian ini sejalan dengan penelitian yang dilakukan oleh Budiman dan Supatmi (2009) yang menguji apakah pemberian Indonesia Sustainability Reporting Award (ISRA) 2005-2008 dan juga penelitian Idealfa (2011) yang menguji apakah Indonesian CSR Award 2005-2008 yang menemukan terdapat perbedaan signifikan antara abnormal return di seputar tanggal pengumuman award. Dari uraian di atas dirumuskan hipotesis sebagai berikut:

$\mathrm{H}_{1}$ : Terdapat perbedaan abnormal return saham perusahaan yang memenangkan award sebelum dan setelah tanggal pengumuman Indonesia Sustainability Reporting Award periode 2009-2011

Salah satu bentuk penghargaan yang diberikan untuk perusahaan yang melaporkan kegiatan bisnis serta kegiatan kepedulian terhadap lingkungan dan sosial adalah ISRA (Indonesia Sustainability Reporting Award). Investor dapat menilai bahwa perusahaan pemenang ISRA memiliki prospek yang baik sehingga minat investor atas perusahaan tersebut meningkat. Untuk mengetahui pengaruh ISRA tahun 2009-2011 digunakan indikator trading volume activity sebagai ukuran yang menggambarkan kegiatan perdagangan saham perusahaan-perusahaan peraih penghargaan ISRA selama tahun 2009-2011. Trading volume activity digunakan untuk melihat apakah investor menilai pengumuman Indonesia Sustainability Reporting Award sebagai salah satu bahan pertimbangan investasi atau tidak sehingga dapat mempengaruhi volume perdagangan saham. Hal tersebut dapat dilihat melalui tinggi rendahnya volume perdagangan saham pada hari-hari di seputar pengumuan ISRA 2009-2011.

Dari penelitian Saputro (2005) yang menganalisis perbedaan harga dan volume perdagangan saham sebelum dan sesudah pengumuman Indonesia Sustainability Reporting Award (ISRA) 2005, ditemukan bahwa tidak terdapat perbedaan volume perdagangan saham yang diukur dengan trading volume activity sebelum dan sesudah pengumuman ISRA 2005. Penelitian ini sejalan dengan penelitian Budiman dan Supatmi (2009) yang tidak menemukan perbedaan signifikan tading value activity di seputar tanggal pengumuman ISRA 2005-2008.

Penelitian yang dilakukan Suwarno (2005) yang menguji apakah penghargaan Annual Report Award (ARA) 2004 direspon positif oleh investor di pasar. Hasil penelitian ini menunjukan adanya peningkatan volume perdagangan saham perusahaan-perusahaan penerima ARA setelah tanggal pengumuman sama seperti Annual Report Award (ARA). Penelitian ini sejalan dengan penelitian yang dilakukan Idealfa (2011) yang menguji apakah pengumuman ICSR Award 2005-2008 direspon positif oleh pasar. Berdasarkan uraian di atas dirumuskan hipotesis sebagai berikut: 
$\mathrm{H}_{2}$ : Terdapat perbedaan trading volume activity (TVA) pada perusahaan yang memenangkan award sebelum dan setelah tanggal pengumuman Indonesia Sustainability Reporting Award periode 2009-2011.

\section{METODE PENELITIAN}

\section{Populasi dan Sampel}

Populasi penelitian ini adalah seluruh perusahaan penerima penghargaan Indonesia Sustainability Reporting Award pada tahun 2009-2011 yang diperoleh dari pengumuman yang dikeluarkan oleh National Center for Sustainability Reporting (NCSR). Metode pengambilan sampel pada penelitian ini adalah metode purposive sampling dengan kriteria sebagai berikut: (1) perusahaan-perusahaan go public pemenang ISRA yang meliputi pemenang utama (winner) dan juga runner-up one dan runner-up two untuk masing-masing kategori, (2) melakukan listing di BEI, (3) tidak melakukan corporate action selama periode penelitian, dan data yang lengkap. Proses pengambilan sampel dapat dilihat pada Tabel 1 .

Tabel 1. Proses Pengambilan Sampel

\begin{tabular}{lcccc}
\hline \multicolumn{1}{c}{ Kriteria } & $\mathbf{2 0 0 9}$ & $\mathbf{2 0 1 0}$ & $\mathbf{2 0 1 1}$ & Jumlah \\
\hline Perusahaan peserta ISRA & 22 & 23 & 36 & 81 \\
$\begin{array}{l}\text { Perusahaan pemenang ISRA (meliputi } \\
\text { runner-up seluruh kategori) }\end{array}$ & 13 & 9 & 13 & 35 \\
$\begin{array}{l}\text { Bukan perusahaan go public } \\
\begin{array}{l}\text { Perusahaan yang melakukan corporate } \\
\text { action selama periode penelitian }\end{array}\end{array}$ & $(3)$ & $(2)$ & $(3)$ & $(8)$ \\
$\begin{array}{l}\text { Perusahaan yang tidak melakukan listing di } \\
\begin{array}{l}\text { BEI } \\
\text { Jumlah sampel yang digunakan dalam }\end{array}\end{array}$ & - & - & - & - \\
penelitian ini & 9 & - & $(1)$ & $(2)$ \\
\hline
\end{tabular}

Data yang digunakan dalam penelitian ini adalah data sekunder berupa harga penutupan saham harian perusahaan yang menerima Indonesia Sustainability Reporting Award 2009, 2010, dan 2011 dalam Indeks Harga Saham Gabungan (IHSG), dan juga data mengenai volume perdagangan saham yang semuanya diperoleh dari www.yahoofinance. com.

\section{Teknik dan Langkah Analisis Data}

Tahapan teknik dan analisis data untuk penelitian ini adalah:

1. Menghitung return sesungguhnya $\left(\mathrm{R}_{\mathrm{i}, \mathrm{t}}\right)$ per perusahaan.

2. Menghitung beta $(\beta)$ per perusahaan dengan menggunakan teknik regresi sederhana dimana return sekuritas $\left(\mathrm{R}_{\mathrm{i} . t}\right)$ sebagai variabel dependen dan return pasar $\left(\mathrm{R}_{\mathrm{m}}\right)$ sebagai variabel independen.

3. Menghitung return ekspektasi $\left(\mathrm{E}\left[\mathrm{R}_{\mathrm{i}, \mathrm{t}}\right]\right)$ per perusahaan.

4. Menghitung abnormal retrun $\left(\mathrm{AR}_{\mathrm{i} . \mathrm{t}}\right)$ per perusahaan.

5. Menghitung rata-rata abnormal return $\left(\mathrm{AAR}_{\mathrm{i} . \mathrm{f}}\right)$ per perusahaan.

6. Menghitung volume perdagangan saham per perusahaan $\left(\mathrm{TVA}_{\mathrm{i} . \mathrm{t}}\right)$.

7. Menghitung rata-rata volume perdagangan saham $\left(\mathrm{XTVA}_{\mathrm{i} . \mathrm{t}}\right)$ per perusahaan. 
8. Menganalisis statistik deskriptif dari abnormal return per perusahaan dan rata-rata abnormal return harian seluruh perusahaan.

9. Menguji hipotesis menggunakan uji beda rata-rata dengan Wilcoxon Signed Test. Wilcoxon Signed Test digunakan karena sampel kurang dari 30 sehingga dianggap tidak normal.

Pengujian Hipotesis menggunakan uji beda rata-rata dengan Wilcoxon Signed Test untuk membandingkan nilai rata-rata dari 2 populasi jika asumsi normalitas tidak terpenuhi (non-parametric method) dengan hipotesis statistik sebagai berikut:

$$
\mathrm{H}_{0}: \mu_{\mathrm{i} 1}=\mu_{\mathrm{i} 2} \quad \mathrm{H}_{\mathrm{a}}: \mu_{\mathrm{i} 1} \neq \mu_{\mathrm{i} 2}
$$

\section{Definisi dan Pengukuran Variabel Penelitian}

Variabel penelitian yang digunakan dalam penelitian ini adalah abnormal return dan trading volume activity.

Abnormal Return (AR). Abnormal return merupakan selisih antara return yang sesungguhnya terjadi dibandingkan dan return ekspektasi (Hartono,1998). Return ekspektasi akan dihitung menggunakan market model dengan periode estimasi 30 hari. Periode jendela 5 hari sebelum dan sesudah tanggal pengumuman. Pengumuman ISRA 2009 jatuh pada tanggal 15 Maret 2009, ISRA 2010 jatuh pada tanggal 16 Desember 2010, ISRA 2011 jatuh pada tanggal 30 November 2011. Perinciannya dapat dilihat melalui Tabel 2.

Tabel 2. Periode Penelitian

\begin{tabular}{ccccc}
\hline Tahun & $(\mathbf{t}-\mathbf{5})$ & $(\mathbf{t}-\mathbf{0})$ & $(\mathbf{t + 5 )}$ & $\begin{array}{c}\text { Periode estimasi return } \\
\text { ekspektasi }\end{array}$ \\
\hline 2009 & 6-13 Maret & 16 Maret & 17-23 Maret & 22 Januari -5 Maret \\
2010 & 9-15 Desember & 16 Desember & 17-23 Desember & 26 Oktober -8 Desember \\
2011 & 23-29 November & 30 November & 1-7 Desember & 12 Oktober -22 November \\
\hline
\end{tabular}

Untuk menentukan abnormal return digunakan rumus:

$$
\mathrm{AR}_{\mathrm{i} . \mathrm{t}}=\mathrm{R}_{\mathrm{i} . \mathrm{t}}-\mathrm{E}\left[\mathrm{R}_{\mathrm{i} . \mathrm{t}}\right]
$$

Di mana :

$$
\mathrm{E}\left(\mathrm{R}_{\mathrm{i} . \mathrm{t}}\right)=\alpha_{\mathrm{i}}+\beta_{\mathrm{i}} \cdot \mathrm{R}_{\mathrm{m} . \mathrm{t}}+\mathrm{e}_{\mathrm{i}}
$$

$$
R_{m . t}=\frac{I H S G_{t}-I H S G_{t-1}}{I H S G_{t-1}} \text { dan } \quad R_{i . t}=\frac{\left[P_{i . t}-P_{i . t-1}\right]}{P_{i . t-1}}
$$

Keterangan:
$\mathrm{AR}_{\mathrm{i} . \mathrm{t}} \quad=$ abnormal return sekuritas ke-i pada periode peristiwa ke- $\mathrm{t}$
$\mathrm{R}_{\mathrm{i} . \mathrm{t}} \quad=$ actual return yang terjadi pada sekuritas ke-i pada periode ke- $\mathrm{t}$
$\mathrm{E}\left[\mathrm{R}_{\mathrm{i} . \mathrm{t}}\right]=$ return ekspektasi sekuritas ke-i
$\alpha_{i} \quad=$ konstanta sekuritas ke- $\mathrm{i}$
$\beta_{\mathrm{i}}^{\mathrm{i}} \quad=$ koefisien beta sekuritas ke-i
$\mathrm{P}_{\mathrm{it}} \quad=$ harga saham sekuritas ke-i pada periode peristiwa ke- $\mathrm{t}$
$\mathrm{P}_{\text {i.t.-1 }}^{\text {i.t }} \quad=$ harga saham sekuritas ke- $\mathrm{i}$ pada periode peristiwa ke $\mathrm{t}-1$ 
$\mathrm{R}_{\mathrm{m} .}=$ actual return pasar yang terjadi pada periode peristiwa ke- $\mathrm{t}$.

$\mathrm{IHSG}_{\mathrm{t}}$ = indeks harga saham gabungan yang terjadi pada periode peristiwa ke-t.

$\mathrm{IHSG}_{\mathrm{t}-1}=$ indeks harga saham gabungan yang terjadi pada periode peristiwa ke- $\mathrm{t}$

Trading Volume Activity (TVA). Menurut Savitri (2001) dalam Idealfa (2011) dijelaskan bahwa trading volume activity digunakan sebagai ukuran volume perdagangan saham yang digunakan untuk melihat apakah investor menilai sebuah pengumuman sebagai sinyal positif atau negatif, atau dengan kata lain apakah informasi tersebut dapat membuat keputusan perdagangan di atas perdagangan normal. TVA dapat dihitung dengan rumus:

$$
\text { TVA it }=\frac{\sum \text { saham perusahaan ke-i yang diperdagangkan dalam waktu } \mathrm{t}}{\sum \text { saham perusahaan ke-i yang beredar dalam waktu } \mathrm{t}}
$$

Setelah TVA masing- masing saham diketahui kemudian dihitung rata-rata TVA selama periode pengamatan dengan rumus:

$$
\text { XTVAt }=\frac{\sum \text { TVAi }}{\mathrm{N}}
$$

Keterangan:

$$
\begin{array}{ll}
\text { XTVAt } & =\text { Rata-rata TVA pada waktu ke-t } \\
\Sigma \text { TVAi } & =\text { Jumlah TVA pada waktu ke-t } \\
\mathrm{n} & =\text { Jumlah sampel }
\end{array}
$$

\section{Pengujian Hipotesis}

Pengujian hipotesis untuk membuktikan adanya reaksi pasar (abnormal return dan trading volume activity) di seputar pengumuman ISRA award dilakukan dengan menggunakan uji beda Wilcoxon Signed Test. Uji beda tersebut membandingkan reaksi pasar pada hari pengumuman ISRA award $(\mathrm{t}-0)$ dengan reaksi pasar mulai lima hari sebelum pengumuman sampai lima hari setelah pengumuman $(\mathrm{t}-5$ sampai dengan $\mathrm{t}+5)$. Level signifikansi yang akan digunakan untuk pengujian hipotesis adalah $1 \%, 5 \%$ dan $10 \%$. Jika signifikansi lebih kecil dari 1\%, 5\% atau 10\%, hipotesis diterima.

\section{PEMBAHASAN HASIL PENELITIAN}

\section{Statistik Deskriptif Abnormal Return}

Abnormal return tertinggi (max), abnormal return terendah (min), dan rata-rata (mean) abnormal return dari seluruh sampel selama periode penelitian akan disajikan di dalam Tabel 3. 
Tabel 3. Rata-rata Abnormal Return

\begin{tabular}{cccc}
\hline Periode & AR maximum & AR minimum & $\begin{array}{c}\text { AAR } \\
\text { (Average Abnormal Return) }\end{array}$ \\
\hline $\mathrm{t}_{-5}$ & 0,017163 & $-0,034113$ & $-0,005241$ \\
$\mathrm{t}_{-4}$ & 0,054324 & $-0,058014$ & 0,003312 \\
$\mathrm{t}_{-3}$ & 0,047352 & $-0,041458$ & $-0,001232$ \\
$\mathrm{t}_{-2}$ & 0,047941 & $-0,047624$ & 0,001620 \\
$\mathrm{t}_{-1}$ & 0,029274 & $-0,030469$ & 0,000944 \\
$\mathrm{t}_{-0}$ & 0,045799 & $-0,034622$ & 0,001889 \\
$\mathrm{t}_{+1}$ & 0,099824 & $-0,022084$ & 0,013532 \\
$\mathrm{t}_{+2}$ & 0,072553 & $-0,046016$ & 0,002134 \\
$\mathrm{t}_{+3}$ & 0,022541 & $-0,044754$ & $-0,007164$ \\
$\mathrm{t}_{+4}$ & 0,088097 & $-0,031910$ & 0,007230 \\
$\mathrm{t}_{+5}$ & 0,034510 & $-0,033205$ & $-0,000470$ \\
\hline
\end{tabular}

Untuk mendapatkan gambaran yang lebih jelas, maka Grafik 1 menggambarkan pola pergerakan nilai rata-rata abnormal return harian saham untuk semua saham perusahaan sampel yang diambil berdasarkan kriteria-kriteria yang sudah tersaji sebelumnya sebagai berikut:

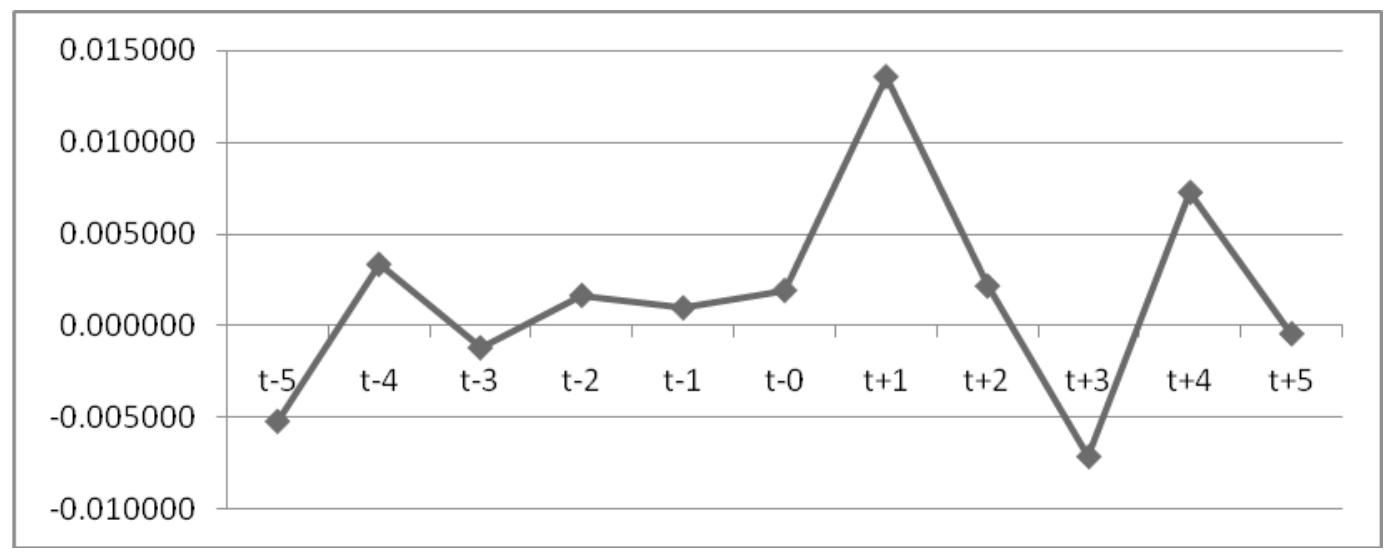

Grafik 1. Rata-rata Abnormal Return

Berdasarkan Grafik 1, rata-rata abnormal return lebih banyak menunjukkan angka yang positif daripada negatif. Angka positif ditunjukkan pada saat t-4, t-2 sampai t+2, dan pada $\mathrm{t}+4$. Adanya abnormal return yang positif diduga disebabkan oleh manfaat penerapan konsep sustainability reporting yang bersifat jangka panjang, maka investor maupun calon investor yang ingin melakukan investasi jangka panjang mau membeli saham pada perusahaan pemenang karena melihat prospek yang cerah di masa yang akan datang dari perusahaan-perusahaan pemenang ISRA yang telah menerapkan konsep sustainability reporting. Meningkatnya abnormal return secara drastis pada sehari setelah tanggal pengumuman ISRA $(\mathrm{t}+1)$ namun kembali menurun pada hari-hari sesudahnya mengindikasikan bahwa pasar merespon adanya pengumuman pemenang ISRA tersebut hanya sehari setelah tanggal pengumuman. 
Abnormal return negatif terjadi pada $\mathrm{t}-5, \mathrm{t}-3, \mathrm{t}+3$, dan $\mathrm{t}+5$ yaitu lima hari sebelum, lima hari sesudah, dan tiga hari sebelum dan tiga hari sesudah tanggal pengumuman. Hal ini terjadi diduga karena investor sengaja melakukan investasi pada hari-hari menjelang diumumkannnya ISRA, yang ditunjukkan dengan nilai yang positif sejak t-2 sampai $t+2$. Terjadinya abnormal return negatif diduga karena investor menganggap pengumuman ISRA adalah sesuatu yang tidak informatif karena proses penjurian ISRA yang hanya mementingkan konsep pengungkapan (disclose) saja tanpa memperhatikan performance perusahaan secara keseluruhan. Hal ini menyebabkan masih banyak investor maupun calon investor yang belum memahami kemanfaatan sustainability reporting yang bersifat jangka panjang. Hal ini mengindikasikan adanya perbedaan rata-rata abnormal return di seputar pengumuman ISRA.

\section{Statistik Deskriptif Trading Volume Activity}

Statistik deskriptif untuk trading volume activity perusahaan sampel selama periode penelitian dapat dilihat dalam Tabel 4.

Tabel 4. Rata-rata Trading Volume Activity

\begin{tabular}{cccc}
\hline Periode & TVA maximum & TVA minimum & Mean Trading Volume Activity \\
\hline $\mathrm{t}_{-5}$ & 0.003024 & 0.000041 & 0.001044 \\
$\mathrm{t}_{-4}$ & 0.003558 & 0.000124 & 0.001147 \\
$\mathrm{t}_{-3}$ & 0.005157 & 0.000103 & 0.001335 \\
$\mathrm{t}_{-2}$ & 0.002252 & 0.000033 & 0.001066 \\
$\mathrm{t}_{-1}$ & 0.004993 & 0.000156 & 0.001572 \\
$\mathrm{t}_{-0}$ & 0.004401 & 0.000051 & 0.001401 \\
$\mathrm{t}_{+1}$ & 0.007118 & 0.000108 & 0.001807 \\
$\mathrm{t}_{+2}$ & 0.005159 & 0.000068 & 0.001004 \\
$\mathrm{t}_{+3}$ & 0.008574 & 0.000061 & 0.001381 \\
$\mathrm{t}_{+4}$ & 0.007505 & 0.000122 & 0.001452 \\
$\mathrm{t}_{+5}$ & 0.010586 & 0.000137 & 0.001809 \\
\hline
\end{tabular}

Untuk mempermudah pemahaman dan memberikan gambaran yang lebih jelas, maka pola pergerakan rata-rata trading volume activity semua sampel disajikan dalam sebuah grafik. Grafik 2 menggambarkan pergerakan nilai rata-rata trading volume activity harian saham untuk semua saham perusahaan sampel yang tertera pada Tabel 4. 


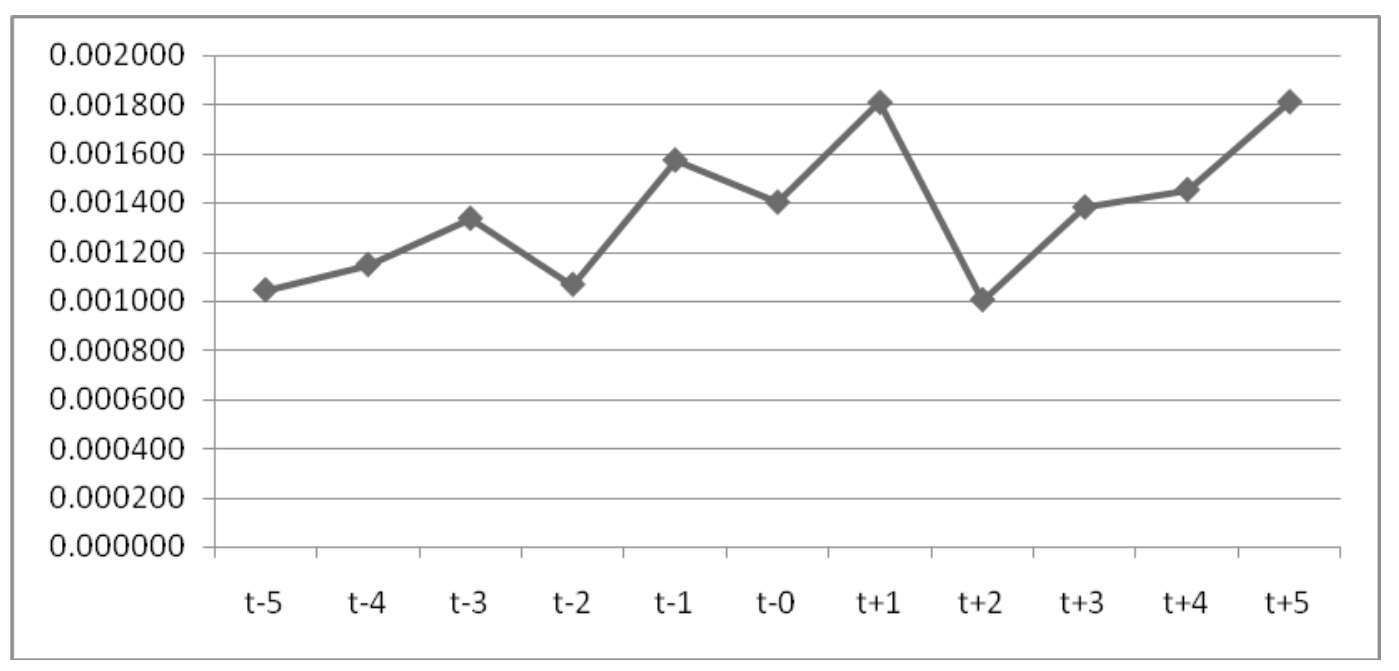

Grafik 2. Rata-rata Trading Volume Activity

Berdasarkan Grafik 2, dapat dilihat bahwa rata-rata trading volume activity semakin meningkat pada saat t-5 sampai dengan t-3 sebelum akhirnya mengalami penurunan pada t-2. Peningkatan rata-rata trading volume activity terjadi sehari sebelum tanggal pengumuman ( $\mathrm{t}-1)$ dan relatif stabil pada saat tanggal pengumuman $(\mathrm{t}-0)$. Rata-rata trading volume activity mencapai puncaknya pada satu hari sesudah tanggal pengumuman $(\mathrm{t}+1)$. Sejalan dengan hasil statistik deskriptif terhadap abnormal return yang menunjukkan bahwa pada $\mathrm{t}+1$, baik rata-rata abnormal return maupun trading volume activity mengalami kenaikan yang cukup signifikan tapat sehari setelah tanggal pengumuman ISRA $(\mathrm{t}+1)$ yang mengindikasikan bahwa pengumuman ISRA mendapat respon yang positif dari pasar. Rata-rata trading volume activity kembali turun dan mencapai titik terendahnya pada $\mathrm{t}+2$. Setelah itu rata-rata trading volume activity mengalami kenaikan pada $t+3$ hingga $t+5$. Hal ini mengindikasikan adanya perbedaan rata-rata trading volume activitydi seputar pengumuman ISRA.

\section{Pengujian terhadap Abnormal Return}

Hasil pengujian hipotesis pertama terhadap abnormal return membuktikan bahwa pengumuman ISRA tidak memiliki kandungan informasi yang dapat mempengaruhi pengambilan keputusan investor, sehingga pasar tidak merespon informasi tersebut. Hal ini dilihat dari ringkasan metode statistik non-parametrik dengan menggunakan Wilcoxon Signed Test dalam Tabel 5. 
Tabel 5. Ringkasan Hasil Pengujian Hipotesis Pertama

\begin{tabular}{cccc}
\hline Keterangan & $\mathrm{Z}$ & $\begin{array}{c}\text { Asymp. Sig. } \\
(2 \text {-tailed })\end{array}$ & Hasil Uji \\
\hline $\mathrm{t}_{-}-\mathrm{t}_{-5}$ & $-0,740$ & 0,459 & $\mathrm{H}_{1}$ Ditolak \\
$\mathrm{t}_{-0}-\mathrm{t}_{-4}$ & $-0,202$ & 0,840 & $\mathrm{H}_{1}$ Ditolak \\
$\mathrm{t}_{-0}-\mathrm{t}_{-3}$ & $-1,090$ & 0,276 & $\mathrm{H}_{1}$ Ditolak \\
$\mathrm{t}_{-0}-\mathrm{t}_{-2}$ & $-0,148$ & 0,882 & $\mathrm{H}_{1}$ Ditolak \\
$\mathrm{t}_{-0}-\mathrm{t}_{-1}$ & $-0,094$ & 0,925 & $\mathrm{H}_{1}$ Ditolak \\
$\mathrm{t}_{-0}-\mathrm{t}_{+1}$ & $-1,574$ & 0,115 & $\mathrm{H}_{1}$ Ditolak \\
$\mathrm{t}_{-0}-\mathrm{t}_{+2}$ & $-0,444$ & 0,657 & $\mathrm{H}_{1}$ Ditolak \\
$\mathrm{t}_{-0}-\mathrm{t}_{+3}$ & $-1,601$ & 0,109 & $\mathrm{H}_{1}$ Ditolak \\
$\mathrm{t}_{-0}-\mathrm{t}_{+4}$ & $-0,498$ & 0,619 & $\mathrm{H}_{1}$ Ditolak \\
$\mathrm{t}_{-0}-\mathrm{t}_{+5}$ & $-0,498$ & 0,619 & $\mathrm{H}_{1}$ Ditolak \\
$\mathrm{t}_{-0}-$ AVRSBLM & $-0,498$ & 0,619 & $\mathrm{H}_{1}$ Ditolak \\
$\mathrm{t}_{-0}-$ AVRSDH & $-0,067$ & 0,946 & \\
\hline
\end{tabular}

Keterangan: $* * *, * * *$ pada tingkat signifikansi $1 \%, 5 \%, 10 \%$

Berdasarkan Tabel 5 di atas, ditemukan bahwa semua signifikansi pengujian abnormal return lebih besar daripada 0,1 hal ini berarti $\mathrm{H}_{1}$ ditolak. Dengan kata lain, tidak ada perbedaan yang signifikan antara rata-rata abnormal return pada tanggal pengumuman ISRA dengan rata-rata abnormal return selama 5 hari sebelum (AVRSBLM) dan 5 hari sesudah (AVRSDH) tanggal pengumuman ISRA award. Tidak adanya perbedaaan raksi pasar tersebut diduga karena investor tidak menganggap bahwa pengumuman pemenang ISRA merupakan sebuah informasi dalam pengambilan keputusan investasi, karena ISRA hanya berfokus pada pengungkapan (disclosure) saja tanpa memperhatikan performance perusahaan secara keseluruhan. Sebab lainnya adalah banyak investor maupun calon investor yang belum memahami manfaat dari sustainability reporting yang bersifat jangka panjang sehingga tidak ada perbedaan yang signifikan dari abnormal return. Jumlah sampel penelitian yang sedikit diduga juga ikut mempengaruhi hasil penelitian sehingga hasil yang diperoleh juga tidak optimal. Studi empiris di Indonesia tentang kemanfaatan penerapan konsep ini juga masih sedikit dan belum belum jelas. Terlebih penerapan sustainability reporting di Indonesia masih bersifat sukarela dan dalam penerapannya membutuhkan dana yang tidak sedikit, bisa jadi investor malah menganggap hal ini sebagai sebuah tindakan pemborosan yang dapat mengurangi laba perusahaan, yang apabila laba berkurang secara signifikan, maka investor jadi enggan melakukan investasi atau dengan kata lain pengumuman ISRA direspon negatif oleh pasar.

Hasil penelitian ini konsisten dengan hasil penelitian Saputro (2005) dan Harsono (2009) yang menemukan bahwa para investor tidak merespon akan adanya ISRA 2005 dan Indonesia CSR Award 2005. Namun bertolak belakang dengan penelitian yang dilakukan oleh Suwarno (2005), Kartini dan Dion (2007), penelitian Idealfa (2011), serta penelitian Budiman dan Supatmi (2009) yang menemukan bahwa pasar berespon atas pengumuman penghargaan pemenang ARA, Indonesia CSR Award 2005 dan 2009, dan ISRA 2005-2008. 


\section{Pengujian terhadap Trading Volume Activity}

Berdasarkan Tabel 6, dapat dilihat bahwa signifikansi pengujian abnormal return pada $\mathrm{t}-5$ dan $\mathrm{t}+2$ lebih kecil dari 0,01 serta signifikansi pada $\mathrm{t}-2$ dan $\mathrm{t}+1$ lebih kecil daripada 0,1 hal ini berarti $\mathrm{H}_{1}$ diterima. Hasil pengujian hipotesis kedua terhadap trading volume activity membuktikan bahwa pengumuman ISRA memiliki kandungan informasi yang dapat mempengaruhi pengambilan keputusan investor, sehingga pasar merespon informasi tersebut.

Tabel 6. Ringkasan Hasil Pengujian Hipotesis Kedua

\begin{tabular}{cccc}
\hline Keterangan & $\mathrm{Z}$ & Asymp. Sig. (2-tailed) & Hasil Uji \\
\hline $\mathrm{t}_{-0}-\mathrm{t}_{-5}$ & $-3,404$ & $0,001^{*}$ & $\mathrm{H}_{2}$ Diterima \\
$\mathrm{t}_{-0}-\mathrm{t}_{-4}$ & $-1,144$ & 0,253 & $\mathrm{H}_{2}$ Ditolak \\
$\mathrm{t}_{-0}-\mathrm{t}_{-3}$ & $-0,632$ & 0,527 & $\mathrm{H}_{2}$ Ditolak \\
$\mathrm{t}_{-0}-\mathrm{t}_{-2}$ & $-1,816$ & $0,069^{* * *}$ & $\mathrm{H}_{2}$ Diterima \\
$\mathrm{t}_{-0}-\mathrm{t}_{-1}$ & $-1,601$ & 0,109 & $\mathrm{H}_{2}$ Ditolak \\
$\mathrm{t}_{-0}-\mathrm{t}_{+1}$ & $-1,735$ & $0,083^{* * *}$ & $\mathrm{H}_{2}$ Diterima \\
$\mathrm{t}_{-0}-\mathrm{t}_{+2}$ & $-2,745$ & $0,006^{*}$ & $\mathrm{H}_{2}$ Diterima \\
$\mathrm{t}_{-0}-\mathrm{t}_{+3}$ & $-1,090$ & 0,276 & $\mathrm{H}_{2}$ Ditolak \\
$\mathrm{t}_{-0}-\mathrm{t}_{+4}$ & $-0,928$ & 0,353 & $\mathrm{H}_{2}$ Ditolak \\
$\mathrm{t}_{-0}-\mathrm{t}_{+5}$ & $-0,094$ & 0,925 & $\mathrm{H}_{2}$ Ditolak \\
$\mathrm{t}_{-0}-\mathrm{AVRSBLM}_{-0}-$ AVRSDH & $-0,955$ & 0,339 & $\mathrm{H}_{2}$ Ditolak \\
$\mathrm{t}_{-0}$ AVRS & $-0,081$ & 0,936 & $\mathrm{H}_{2}$ Ditolak \\
\hline
\end{tabular}

Keterangan: *,**,*** pada tingkat signifikansi $1 \%, 5 \%$ dan $10 \%$

Sejalan dengan pengujian hipotesis terhadap abnormal return, pengujian hipotesis terhadap trading volume activity memberikan bukti bahwa tidak terdapat perbedaaan yang signifikan rata-rata trading volume activitypada 5 hari sebelum (AVRSBLM) maupun 5 hari sesudah (AVRSDH) tanggal diumumkannya ISRA. Namun, jika dilihat dari rata-rata trading volume activity harian, ditemukan bahwa pada $\mathrm{t}-0-\mathrm{t}-5, \mathrm{t}-0 \mathrm{-t}-2$, dan $\mathrm{t}-0-\mathrm{t}+1$ terjadi perbedaan yang signifikan antara rata-rata trading volume activity. Hal ini mengindikasikan bahwa pasar merespon adanya ISRA tahun 2009-2011 dengan memanfaatkan momen jangka pendek yang terjadi sebelum tanggal pengumuman ISRA yaitu pada $\mathrm{t}-5$ dan $\mathrm{t}-2$. Karena tanggal pengumuman pemenang ISRA hanya bersifat formalitas, sedangkan informasi tentang perusahaan pemenang telah diketahui secara umum oleh investor maupun calon investor, maka kemungkinan pasar sudah merespon positif pengumuman pemenang ISRA sebelum tanggal pengumuman. Perbedaan signifikan juga ditemukan pada $\mathrm{t}+1$ atau hari setelah pengumuman ISRA. Hal ini disebabkan karena investor dan calon investor, yang tadinya hanya memprediksi perusahaan pemenang, pada sehari setelah tanggal pengumuman telah mendapatkan daftar pemenang ISRA yang resmi. Sehingga dimungkinkan baik investor maupun calon investor sudah yakin untuk melakukan investasi pada perusahaan pemenang, hal ini ditunjukkan dengan adanya lonjakan rata-rata trading volume activity maupun rata-rata abnormal return tapat sehari setelah tanggal pengumuman pemenang ISRA. Hasil pengujian ini menunjukkan bahwa ada perbedaan trading volume activitydi seputar tanggal pengumuman Indonesia Sustainability Reporting Award (ISRA) 2009-2011. 
Hasil penelitian ini sejalan dengan penelitian dilakukan Suwarno (2005), penelitian Idealfa (2011), serta penelitian Kartini dan Dion (2007) yang menyatakan bahwa terdapat perbedaan rata-rata trading volume activity yang signifikan di seputar tanggal pengumuman penghargaan. Namun penelitian ini bertolak belakang dengan penelitian Saputro (2005), serta penelitian Budiman dan Supatmi (2009) yang juga menemukan tidak terdapat perbedaan TVA baik di seputar tanggal pengumuman award.

\section{KESIMPULAN}

Berdasarkan hasil pengujian terhadap abnormal return maka dapat disimpulkan $\mathrm{H}_{1}$ ditolak, hal ini berarti bahwa tidak ditemukan perbedaan yang signifikan antara abnormal return di seputar tanggal pengumuman pemenang Indonesia Sustainability Reporting Award 2009-2011 baik pada rata-rata harian abnormal return sebelum maupun sesudah $(\mathrm{t}-5, \mathrm{t}-4, \mathrm{t}-3, \mathrm{t}-2, \mathrm{t}-1, \mathrm{t}+1, \mathrm{t}+2, \mathrm{t}+3, \mathrm{t}+4, \mathrm{t}+5)$, dan juga rata-rata abnormal return 5 hari sebelum (AVRSBLM) dan 5 hari sesudah (AVRSDH).

Penelitian ini juga menemukan bahwa berdasarkan hasil pengujian terhadap trading volume activity ditemukan bahwa $\mathrm{H}_{2}$ diterima. Hal ini berarti ada perbedaan rata-rata trading volume activity yang signifikan, terutama pada hari kelima (t-5) dan kedua ( $\mathrm{t}-2)$ sebelum tanggal pengumuman, dan sehari setelah tanggal pengumuman $(\mathrm{t}+1)$ pemenang ISRA 2009-2011. Namun tidak ada perbedaan signifikan antara rata-rata trading volume activity pada 5 hari sebelum (AVRSBLM) maupun 5 hari sesudah (AVRSDH).

\section{Implikasi Terapan}

Hasil penelitian ini diharapkan dapat memberi masukan kepada perusahaan, hasil penelitian membuktikan bahwa pengumuman Indonesia Sustainability Reporting Award 2009-2011 berdampak terhadap abnormal return maupun trading volume activity, meski pengaruh terhadap abnormal return tidak signifikan, namun terdapat pengaruh signifikan terhadap trading volume activity. Sustainability reporting akan memberikan manfaat jangka panjang. Oleh karena itu, perusahaan yang sudah menerapkan sustainablity reporting sebaiknya lebih meningkatkan penerapan tanggung jawab kepada lingkungan sosial, maupun lingkungan alam di samping maksimalisasi profit. Bagi perusahaan yang belum menerapkan konsep sustainability reporting diharapkan mampu menerapkan konsep tersebut sebagai tanggung jawab sosialnya. Salah satu manfaat bagi perusahaan yang telah menerapkan konsep sustainability reporting dengan baik adalah mendapat citra positif dari masyarakat, yang tentunya menjadi nilai tambah bagi perusahaan. Sehingga investor maupun calon investor tertarik berinvestasi pada perusahaan tersebut.

Bagi investor, dilihat dari analisis deskriptif bahwa hasil penelitian ini menemukan adanya pergerakan abnormal return dan trading volume activity di sekitar tanggal pengumuman ISRA 2009-2011. Secara statistik, meski tidak berpengaruh secara signifikan terhadap abnormal return saham, namun hasil penelitian ini berpengaruh secara signifikan terhadap trading volume activity. Investor diharapkan dapat memanfaatkan adanya pengumuman pemenang award ini sebagai bahan pertimbangan dalm keputusan investasi. Karena kemungkinan di masa yang akan datang perusahaan yang menerapkan konsep sustainability reporting akan bertambah banyak dengan kinerja yang semakin meningkat ke arah yang lebih baik. 


\section{Keterbatasan}

Penelitian ini masih terdapat keterbatasan yaitu sampel yang digunakan jumlahnya terbatas hanya dua puluh lima perusahaan dan mungkin kurang memadai untuk pengujian hipotesis yang ada. Maka saran yang dapat digunakan dalam penelitian mendatang adalah memperpanjang periode penelitian, sehingga dapat diperoleh sampel penelitian yang lebih banyak. Penggunaan model perhitungan abnormal return yang berbeda selain Market Model yaitu Mean Adjusted Model atau Market Adjusted Model sehingga diharapkan mampu memberikan hasil yang lebih baik dalam penelitian selanjutnya.

\section{REFEREENSI}

Anggraini, Fr.R. Retno. 2006. Pengungkapan Informasi Sosial dan Faktor-Faktor yang Mempengaruhi Pengungkapan Informasi Sosial dalam Laporan Keuangan Tahunan (Studi Empiris pada Perusahaan-Perusahaan yang terdaftar di Bursa Efek Jakarta). Simposium Nasional Akuntansi IX. Padang. Agustus: 54-58.

Anggraini, Nenny. 2007. Corporate Social Responsibility (CSR). Buletin Ekonomi, September 2007 Vol. XI No.2.

Bandi dan J. Hartono. 1999. Perilaku Harga dan Volume Perdagangan Saham Terhadap Pengumuman Dividen. Jurnal SNA2, UBRAW.

Budiman dan Supatmi. 2009. Pengaruh Pengumuman Indonesia Sustainability Reporting Award (ISRA) Terhadap Abnormal Return dan Volume Perdagangan Saham(Studi Kasus Pada Perusahaan Pemenang ISRA Periode 2005-2008). Simposium Nasional Akuntansi (SNA) XII, Palembang.

Daniri, M. Achmad. 2008. Standarisasi Tanggung Jawab Sosial Perusahaan. http://www. madaniri.com. Diakses Tanggal 29 juli 2011.

Darwin, Ali. 2004. Penerapan Sustainability Reporting di Indonesia. Konvensi Nasional Akuntansi V, Program Profesi Lanjutan. Yogyakarta, 13-15 Desember.

Gray, Kouhy and Lavers. 1995. Corporate Social and Environmental Reporting: A Review of the Literature And a Longitudinal Study Of UK Disclosure. Accounting, Auditing and Accountability. Vol. 8 No 2.

Global Reporting Initiative (GRI). 2004. The Sustainability Reporting: A Report of TBL (Triple Bottom Line). http://www.globalreporting.org. Diakses Tanggal 1 Agustus 2011.

Guthrie, J. and Mathews, M.R. (1985), Corporate social accounting in Australasia, Research in Corporate Social Performance and Policy, Vol. 7, pp. 251-277

Hamzah, Ardi. 2007. Pengaruh Kandungan Informasi Laba, Arus Kas Operasi, dan Deviden terhadap Abnormal Return. Jurnal NeO-Bis, Volume 1, No.1, JuliDesember 2007.

Harsono F, Diana. 2009. Dampak Indonesian CSR Award 2005 Terhadap Abnormal Return Saham. Skripsi Program S1 Fakultas Ekonomika dan Bisnis Universitas Kristen Satya Wacana (tidak dipublikasikan). 
Hartono, Jogiyanto. 1998. Teori Portofolio dan AnalisisInvestasi. BPFE. Yogyakarta. Indonesia Marketing Asociation. 2006.

Idealfa, D. Neogo. 2011. Dampak Indonesia Corporate Social Responsibility (ICSR) Award terhadap Abnormal Return dan Trading volume activity (Studi pada Perusahaan Pemenang Indonesian CSR Award yang terdaftar di BEI Periode 2005 dan 2008). Skripsi Program S1 Fakultas Ekonomika dan Bisnis Universitas Kristen Satya Wacana (tidak dipublikasikan).

Kartini dan Dion. 2007. Analisis Reaksi Saham Perusahaan Penerima Penghargaan Annual Report Award (ARA) 2005 yang terdaftar di Bursa Efek Indonesia. Jurnal Keuangan dan Perbankan, XI, No.3 September: 421-430.

Mulia, Puji. 2005. Pengaruh Pengumuman Rights Issue terhadap Tingkat Keuntungan dan Volume Perdagangan Saham (Studi empiris perusahaan-perusahaan yang listing di BEJ periode 2001-2003). Skripsi Program S1 Fakultas Ekonomika dan Bisnis Universitas Kristen Satya Wacana (tidak dipublikasikan).

Panitia dan Dewan Juri Penghargaan Indonesia Sustainability Reporting Award 2010. Press Release. Diakses dari http://www.ncsr-id.org. diakses pada 29 Juli 2011

Panitia dan Dewan Juri Penghargaan Indonesia Sustainability Reporting Award 2011. Press Release. Diakses dari http://www.ncsr-id.org. diakses pada 9 April 2012

Saputro. 2005. Analisis Perbedaan Harga dan Volume saham sebelum dan sesudah Pengumuman Indonesia Sustainability Reporting Award 2005. http:// www. jurnalskripsi.com . diakses pada 1 Agustus 2011.

Sulistyanto, H.S. dan Prapti M.S, 2003. Good Corporate Governance: Bisakah meningkatkan kepercayaan masyarakat?. Jurnal Ekonomi dan Bisnis, Vol. 4, No.1, Januari: 83-93.

Suwarno. 2005. Pengaruh Annual Report Award (ARA) 2004 terhadap Abnormal Return dan Volume Perdagangan Saham di Bursa Efek Jakarta. Skripsi Program S1 Fakultas Ekonomika dan Bisnis Universitas Kristen Satya Wacana (tidak dipublikasikan). 